\title{
ALGATERMESZTŐ RENDSZER ENERGETIKAI HATÁSFOKÁT BEFOLYÁSOLÓ TÉNYEZŐK VIZSGÁLATA
}

\section{PARAMETERS OF ENERGY EFFICIENCY IN ALGAE CULTIVATING SYSTEMS}

\author{
Bocsi Róbert ${ }^{1}$, Rippelné Pethő Dóra ${ }^{2}$, Horváth Géza ${ }^{3}$, Hanák László ${ }^{4}$, Hodai Zoltán ${ }^{5}$ \\ Pannon Egyetem, Mérnöki Kar, Vegyészmérnöki- és Folyamatmérnöki Intézet, Ve- \\ gyipari Müveleti Intézeti Tanszék, H-8200 Magyarország, Veszprém, Egyetem u. 10. \\ Telefon: +36-88-624-268, \\ Ibocsirobert@almos.uni-pannon.hu \\ 2pethod@almos.uni-pannon.hu \\ 33orvathg@almos.uni-pannon.hu \\ ${ }^{4}$ hanakl@almos.uni-pannon.hu \\ 5hodaiz@almos.uni-pannon.hu
}

\begin{abstract}
For the characterization of the energy recovery technologies the most important parameter is the energy balance. While the amount of energy invested in algae cultivation system can be measured directly, the magnitude of utilization can be calculated only after the subsequent conversion steps. This paper presents the elements of energy needs arising from heterotrophic microalgae cultivation. It can be realized by using that sources, which can be accessible in ready-to-use form.
\end{abstract}

Keywords: microalgae, cultivation, photobioreactor, energy efficiency

\section{Összefoglalás}

Az energetikai hasznosításra szánt technológiák jellemzésére az egyik legfontosabb jellemző az energiamérleg. Míg a befektetett energia mennyiségét közvetlenül lehet mérni, a hasznosulást, a lipidtermelést már csak a későbbi konverziós lépések után lehet megadni. Jelen dolgozat a heterotróf mikroalga termesztés során felmerülö energiaigény kielégítésének elemeit mutatja be. Ezt számos forrásból megvalósíthatjuk, melyek közül a korlátlanul rendelkezésre állókat fontos felhasználni.

Kulcsszavak: mikroalga, algatermesztés, fotobioreaktor, energiahatékonyság

\section{Bevezetés}

A világ összes biöüzemanyag termelése 2014-ben megközelítette a 71 Mtoe ( 2,96 EJ) éves mennyiséget, melynek több, mint $50 \%$-a biodízel volt. A BP által készített tanulmány szerint az éves bioüzemanyag termelés 2013-2014 idő- szakban 7,4 \%-kal nött, ezért is indokolt az algák ilyetén felhasználási lehetőségeinek kutatása, a jelenleg alkalmazott technológiák fejlesztése. [1]

Egy algatechnológiai rendszer üzemeltetése során tekintettel kell lennünk arra, hogy a termék felhasználás céljától szenm 
elött tartva az energiaminimumra törekedve alakítsuk ki a termesztési technológiát.

\section{Az energiaforgalom az algater- mesztésben}

A termesztése során a mikroalgaszuszpenziót alkotó sejtek alábbi igényeit szükséges kielégíteni :

- fényigény;

- szénforrás igény;

- keverés igény;

- hűtési/fütési igény.

\subsection{A mikroalgák fényigényének ki- elégítése}

A kultúra számára elérhető fény menynyisége és minősége a fotoszintetizáló szervezetek számára egy alapvetően korlátozó tényező. Fontos azonban megjegyezni, hogy nem minden algafaj képes 24 órás megvilágításban szaporodási sebességének maximumát elérni. A legtöbb faj úgy tudja biomassza termelékenységének maximumát adni, ha világos és sötét szakaszok váltják egymást. Ezt természetes fénynél nem, csak mesterséges megvilágítás esetén fontos figyelembe venni. Fotoszintézisre a napfény spektrumából csak a 400-700 nm közötti hullámhossz intervallum hasznosítható. A mikroalgák fotoszintézisük során a rendelkezésre álló napfénynek 6-7\%-át képesek használni, míg a hasznosulás elvi maximuma $9 \%$.

A legkézenfekvőbb megoldás nagylépétékü algatermesztő rendszerek esetén a napfény alkalmazása. Bár a villamosenergia igény ezzel minimálható, de további nehézségek adódnak. Szabadtéri termesztés esetén az egyre növekvő biomassza koncentráció növekedésével a szuszpenzió fényabszorpciós képessége is növekszik, így a szuszpenzió jelentős melegedésére lehet számítani, melynek során hütési energiaigény jelenkezik.

A fényigény kielégítésére mesterséges fényforrások is használhatók, de ez esetben nem csak a villamosenergia szükséglet fedezésésre kell energiát befektetni. A mesterséges fényforrások esetén fajtától függöen különböző spektrumú fényt sugároznak (1. táblázta), amelyből a hasznosítható fény mennyisége arányos a PAR tartománybeli fotonok mennyiségével. Az üzemidő előrehaladtával különböző mértékü fényáram csökkenés figyelhető meg és bizonyos fényforrás típusoknál az energiahasznosulás hatásfokát a termelödő hő szintén jelentősen csökkenti. [2], [3]

1. táblázat. Mesterséges fényforrások hatásfoka a PAR tartományban

\begin{tabular}{|c|c|}
\hline Fényforrás & $\mu \mathrm{mol}$ PAR foton/(W.s) \\
\hline LED források & $1,8-2,6$ \\
\hline HID & $1,6-1,87$ \\
\hline $\begin{array}{c}\text { hagyományos } \\
\text { fénycső }\end{array}$ & 1,25 \\
\hline $\begin{array}{c}\text { speciális } \\
\text { fénycsö }\end{array}$ & $1,8-2,2$ \\
\hline
\end{tabular}

A fényhasznosulást a nem csak a fényforrás minősége, hanem a termesztő rendszer fajlagos fényabszorpciós felülete és annak fényáteresztő képessége is befolyásolja.

\subsection{Szénforrások mikroalgák ter- mesztéséhez}

Heterotróf termesztés esetén a mikroalga szuszpenzióban fellehető szénforrás a széndioxid oldott vagy hidrogénkarbonát ion formában hozzáférhető az algák számára. A legkézenfekvőbb megoldás, ha olyan forrást alkalmazunk, amely egy természetes előfordulásból vagy egy technológia mellékáramaként jelentkezik. Ilyen lehet a füstgázok, a biogáz vagy természetes előfordulások széndioxid tartalma. Többletenergia befektetésre akkor van szükség, ha a befúvásra kerülő gázelegy nyomása nem elegendő a szuszpenzión és a gázelosztó rendszeren történő átáramoltatáshoz. 
A nem tiszta szén-dioxid forrás használata esetén számításba kell venni azt az energia igényt amely azoknak a komponenseknek a részleges vagy teljes eltávolításához szükséges, amelyek termesztéstechnológiai szempontból limitáló tényezők $\left(\mathrm{SO}_{2}\right.$, $\left.\mathrm{H}_{2} \mathrm{~S}\right)$. [4], [5]

2. táblázat. Az ipari füstgázokban fellehetö komponensek és koncentrációik [6]

\begin{tabular}{|c|c|}
\hline Komponens & Koncentráció \\
\hline $\mathrm{N}_{2}$ & $70-75(\mathrm{~V} / \mathrm{V}) \%$ \\
\hline $\mathrm{CO}_{2}$ & $5-25(\mathrm{~V} / \mathrm{V}) \%$ \\
\hline $\mathrm{H}_{2} \mathrm{O}$ & $9-14(\mathrm{~V} / \mathrm{V}) \%$ \\
\hline $\mathrm{O}_{2}$ & $0,7-10(\mathrm{~V} / \mathrm{V}) \%$ \\
\hline $\mathrm{SO}_{2}$ & $0-1500 \mathrm{ppm}$ \\
\hline $\mathrm{CO}$ & $50-150 \mathrm{ppm}$ \\
\hline por & $100-800 \mathrm{ppm}$ \\
\hline nehézfémek & $0,05-0,5 \mathrm{ppm}$ \\
\hline
\end{tabular}

\subsection{Az algaszuszpenzió keverési igé- nye}

Az algaszuszpenziót két ok miatt mindenképpen szükséges keverni. Az egyik, hogy a széndioxid beoldódását intenzifikáljuk. A megfelelő gázeloszlatás révén a gázáram szükségszerüen keveri a közeget, de ha koncentráció gradiens alakul ki a termesztőrendszerben, további, mechanikai keverésre van szükség. Ez utóbbi különösen a szabadtéri, raceway pondok esetén elkerülhetetlen. [7]

A másik ok, ami miatt keverési igény lép fel a szuszpenzióban az optikai denzitás. Minél nagyobb a biomassza koncentráció, annál vékonyabb réteget lehet átvilágítani konstans fényárammal. Ekkor azok a rétegek, amelyekbe kevesebb fény jut, az algák szaporodásában a fényhiány limitáló hatása miatt a szaporodás lelassul majd bomlás indul be. Ennek elkerülésére szükséges a nagy optikai denzitással bíró szuszpenziók keverése. A fajlagos keverési igény a reaktor konstrukciótól és a fajlagos gázterheléstől függően különböző lehet. [8]

\subsection{Az algaszuszpenzió hütése/fútése}

Mivel a beeső fénynek csak kevesebb, mint $10 \%$-a hasznosul, egy sürü szuszpenzió (3-4 g alga szárazanyag/dm3) melegedése természetes fényben jelentős. Emiatt a reaktor hömérséklete hütés nélkül, intenzív napsugárzás esetén a léghőmérsékletnél jóval magasabb is lehet. Az algák optimális szaporodóképessége $20-40{ }^{\circ} \mathrm{C}$ hőmérséklettartományban tartható meg. Ez alatt anyagcseréjük és ezzel együtt szaporodásuk jelentősen lelassul, míg e tartomány feletti hőmérsékleten jelentősen nő a hősokk okozta algapusztulás veszélye. Az optimális tartományon belül exponenciális növekmény tapasztalható a biomassza tömegben. Éppen ezért a temperáló rendszert mindig az adott termesztő rendszer konstrukciójához illesztik. [9]

\section{Következtetések}

A termesztési paraméterek helyes megválasztása alapvetően befolyásolja a teljes folyamat sikerességét. Fontos megjegyezni, hogy a termesztési periódus alatt elért biomassza-koncentráció és lipidtartalom értékek a termesztési technika, a környezeti valamint az ésszerüen szabályozható müködési paraméterek függvényében jelentős különbségeket mutathatnak. A telephelyen rendelkezésre álló mellékáramok összetevőinek és kinetikai energiájának kihasználása a termesztés energiamérlegének pozitív eltolódását hozhatja. Ugyanakkor újabb paraméterek befolyásolhatják a termesztés sikerességét attól függően, hogy a felhasznált áramok összetétele és az egyéb paraméterei miylen változékonyságot mutat.

\section{Szakirodalmi hivatkozások}

[1] BP Statistical Review of World Energy, June 2015, bp.com/statisticalreview, 2016.02.04.

[2] Ogbonna JC, Tanaka H : Light requirement and photosynthetic cell cultivation: development of processes for efficient light utilization in photobioreactors, J. Appl. Phycol., 2000 10: 555-559. 
[3] Ward Blanken, Maria Cuaresma, René H. Wijffels, Marcel Janssen: Cultivation of microalgae on artificial light comes at a cost, Algal Research, Volume 2, Issue 4, October 2013, Pages 333-340, ISSN 2211-9264, http://dx.doi.org/10.1016/j.algal.2013.09.004.

[4] Doucha, J., Straka, F., Livansky, K., 2005. Utilization of flue gas for cultivation of microalgae (Chlorella sp.) in an outdoor open thin-layer photobioreactor. J. Appl. Phycol. 17, 403-412.

[5] Chien-Ya Kao, Sheng-Yi Chiu, Tzu-Ting Huang, Le Dai, Guan-Hua Wang, Ching-Ping Tseng, Chiun-Hsun Chen, Chih-Sheng Lin: $A$ mutant strain of microalga Chlorella sp. for the carbon dioxide capture from biogas, Biomass and Bioenergy, Volume 36, January 2012, Pages 132-140, ISSN 0961-9534, 10.1016/j.biombioe.2011.10.046.

[6] Sofie Van Den Hende, Han Vervaeren, Nico Boon: Flue gas compounds and microalgae: (Bio-)chemical interactions leading to biotechnological opportunities, Biotechnology Advances, Volume 30, Issue 6, November-December 2012, Pages 1405-1424, ISSN http://dx.doi.org/10.1016/j.biotechadv.2012.0 2.015 .

[7] Jinsoo Kim, Joo-Youp Lee, Ting Lu: Effects of dissolved inorganic carbon and mixing on autotrophic growth of Chlorella vulgaris, Biochemical Engineering Journal, Volume 82, 15 January 2014, Pages 34-40, ISSN 1369-703X, http://dx.doi.org/10.1016/j.bej.2013.11.007.

[8] Kanhaiya Kumar, Anusha Sirasale, Debabrata Das: Use of image analysis tool for the development of light distribution pattern inside the photobioreactor for the algal cultivation, Bioresource Technology, Volume 143, September 2013, Pages 88-95, ISSN 0960-8524, http://dx.doi.org/10.1016/j.biortech.2013.05.1 17.

[9] M.J. Raeesossadati, H. Ahmadzadeh, M.P. McHenry, N.R. Moheimani: $\mathrm{CO} 2$ bioremediation by microalgae in photobioreactors: Impacts of biomass and $\mathrm{CO} 2$ concentrations, light, and temperature, Algal Research, Volume 6, Part A, October 2014, Pages 78-85, ISSN 2211-9264, http://dx.doi.org/10.1016/j.algal.2014.09.007. 